УДК 378

https://doi.org/10.52058/2786-5274-2022-1(3)-257-264

Криштанович Мирослав Франкович доктор наук 3 державного управління, професор, професор кафедри педагогіки та інноваційної освіти, Інститут права, психології та інноваційної освіти, Національний університет «Львівська політехніка», вул. Степана Бандери, 12, м. Львів, 79000, тел.: (067) 793-31-53, https://orcid.org/0000-0003-1750-6385

Гродзь Наталія Миколаївна аспірантка кафедри педагогіки та інноваційної освіти, Національний університет "Львівська політехніка", вул. Степана Бандери, 12, м. Львів, 79000, тел.: (097) 470-25-44, https://orcid.org/0000-0003-1577-1214

\title{
АНАЛІЗ ОСНОВНИХ АСПЕКТІВ ВПЛИВУ СОVID-19 НА ПРОФЕСІЙНУ ПІДГОТОВКУ МАЙБУТНІХ ВЧИТЕЛІВ: МІЖНАРОДНИЙ ДОСВІД
}

Анотація. В 2019 році в одній з китайських провінцій був зареєстрований випадок пневмонії, зумовленої вірусом COVID-19, який в наступному вразить пандемією коронавірусної хвороби всі континенти нашої планети. Слово «COVID-19» стало синонімом мільйонів смертей та тілесних страждань, суворих карантинних обмежень та економічних проблем, які вразили всі суспільні сфери життя населення світу. Даний вірус виявив прогалини у системах охорони здоров'я та протиепідемічного захисту багатьох країн. Вперше навіть найбільш розвинуті країни опинились в розпачі від банальної відсутності кисню для хворих людей своєї країни. Коронавірусна хвороба отримала статус пандемії в березні 2020 року.

Пандемія COVID-19 привела до величезних людських жертв у всьому світі і являє собою безпрецедентну проблему для суспільної охорони здоров'я, продовольчих систем і сфери праці. Економічні і соціальні потрясіння, викликані пандемією, $є$ руйнівними: десятки мільйонів людей опинились в зоні бідності, в той час як число тих, хто недоїдає, яке в допандемічні часи оцінювались майже в 690 мільйонів, виросло на 132 мільйонів до кінця 2021 року.

Метою дослідження $є$ аналіз основних аспектів впливу covid-19 на професійну підготовку майбутніх вчителів. Для цього було проведено дослідження зарубіжного досвіду та застосовано ряд теоретико-наукових методів аналізу та синтезу опрацьованої інформації. Визначено, що пандемія COVID-19 змусила всі освітні школи по всьому світу перейти на викладання і навчання в Інтернеті. Таким чином, урядам слід масштабувати мережеву 
інфраструктуру і підключення до Інтернету в міських і сільських районах. Країни повинні розробити стратегію масштабування освітніх технологій, створити освітні ресурси з нульовим рейтингом в Інтернеті, підготувати цифрові ресурси для викладання і навчання, використовувати безкоштовні ресурси для онлайн-навчання, використовувати мобільний навчання, використовувати радіо і телебачення, а також розвивати інфраструктуру інформаційно-комунікаційних технологій. Країни, що розвиваються повинні масштабувати інфраструктуру онлайн-навчання.

Ключові слова: пандемія, COVID-19, освіта, професійна підготовка, вчителі.

Kryshtanovych Myroslav Frankovych Doctor of Science in Public Administration, Professor, Professor of the Department of Pedagogy and Innovative Education, Institute of Law, Psychology and Innovative Education, Lviv Polytechnic National University, 12 Stepana Bandera St., Lviv, 79000, tel.: (067) 793-31-53, https://orcid.org/0000-0003-1750-6385

Grodz Natalia Mykolaivna Postgraduate student of the Department of Pedagogy and Innovative Education, Institute of Law, Psychology and Innovative Education, Lviv Polytechnic National University, 12 Stepana Bandera St., Lviv, 79000, tel.: (097) 470-25-44, https//orcid.org/0000-0003-1577-1214

\section{ANALYSIS OF THE BASIC ASPECTS OF THE INFLUENCE OF COVID-19 ON THE PROFESSIONAL TRAINING OF THE FUTURE TEACHER: INTERNATIONAL EXPERIENCE}

Abstract. In 2019, a case of pneumonia caused by the COVID-19 virus was reported in one of the Chinese provinces, which next will hit all continents of our planet with a coronavirus pandemic. The word "COVID-19" has become synonymous with millions of deaths and physical suffering, severe quarantine restrictions and economic problems that have affected all social areas of the world's population. This virus has revealed gaps in health systems and anti-epidemic defenses in many countries. For the first time, even the most developed countries were in despair from the banal lack of oxygen for the sick people of their country. Coronavirus disease received pandemic status in March 2020.

The COVID-19 pandemic has caused enormous loss of life worldwide and poses an unprecedented challenge to public health, food systems and the world of work. The economic and social shocks caused by the pandemic are devastating: tens of millions of people are trapped in poverty, while the number of undernourished, estimated at nearly 690 million in pre-pandemic times, has grown by 132 million by the end of 2021.

The aim of the study is to analyze the main aspects of the impact of covid-19 on the professional training of future teachers. For this, a study of foreign experience 
was carried out and a number of theoretical and scientific methods of analysis and synthesis of the developed information were applied. It is determined that the COVID-19 pandemic has forced all educational schools around the world to switch to online teaching and learning. Therefore, governments should scale up network infrastructure and Internet connectivity in urban and rural areas. Countries should develop a strategy for scaling educational technologies, create zero-rated educational resources on the Internet, prepare digital resources for teaching and learning, use free resources for online learning, use mobile learning, use radio and television, and develop information and communication technology infrastructure. Developing countries must scale up their online learning infrastructure.

Keywords: pandemic, COVID-19, education, training, teachers

Постановка проблеми. Пандемія COVID-19 привела до величезних людських жертв у всьому світі і являє собою безпрецедентну проблему для суспільної охорони здоров'я, продовольчих систем і сфери праці.

Суворі обмежувальні заходи щодо протидії поширення вірусу зумовили значний негативний вплив на світову економіку. Політика «жорстких обмежень», а зокрема ізоляційні обмеження, вплинули на рівень продуктивності пересічних працівників. Це зумовлено тим, що працівникам заборонили працювати на своєму робочому місці, вони були змушені працювати з дому, що в значні мірі сповільнило робочий процес. Окрім того до заходів політики «жорстких обмежень» входило повна чи часткова заборона публічних заходів, відвідування туристичних та рекреаційних об’єктів, що в значній мірі вдарило по світовому туризму. До прикладу, згідно статистики 2020 року, в певних секторах сферу туризму та гостьового бізнесу підприємства стикнулись з рекордним спадом ділової активності - 90\%. Це зумовлено тим, що підприємства залежать від соціальної активності, особливо в секторах туризму і рекреації, які пережили спад, і більшість їх співробітників позбулися засобів до існування через скорочення робочих місць і звільнень. Це призвело до зниження споживання постраждалих і збільшило невпевненість людей у витратах, що призвело до закриття багатьох підприємств i ïх руйнувань. Замість цього більшість країн відмітили в 2020 році різке зниження економічного зростання, що призведе до падіння їх валового внутрішнього продукту. Вплив коронавірусної пандемії та карантинних обмежень не оминув і сферу освіти.

Аналіз останніх досліджень і публікацій. Важливі аспекти підготовки майбутніх вчителів в закладах вищої освіти висвітлюються такими ученими як I А. Павленко, А. Федорченко, М. Окландер, Н. Савицька, Н. Чухрай, T. Решетнікова, I. Лилик та інші. Однак настання пандемії і вплив COVID-19 суттєво змінити правила ведення педагогічної діяльності, що і зумовило вибір даної тематики і їі сучасну актуальність. 
Метою дослідження $\epsilon$ аналіз основних аспектів впливу COVID-19 на професійну підготовку майбутніх вчителів. Для цього було проведено дослідження зарубіжного досвіду та застосовано ряд теоретико-наукових методів аналізу та синтезу опрацьованої інформації.

Виклад основного матеріалу. Як нами було зазначено, Вплив коронавірусної пандемії та карантинних обмежень не оминув і сферу освіти. Але варто зазначити, що дана сфера була однією з небагатьох, яка попри значні втрати отримала потужний стимул до тотальної модернізації застарілих методів надання освітніх послуг розвитку. Всі освітні заклади в тій чи іншій мірі були зобов'язані зачинити свої двері та перейти на дистанційну форму освіти.

В результаті карантинних обмежень, станом на середину 2020 року, 1,5 млрд учнів та студентів по всьому світу опинились відрізаними від можливостей отримати освітні послуги в тій чи іншій мірі.

Велика кількість учнів шкіл та студентів вищих навчальних закладів по всьому світу були змушені перейти на дистанційні форми освіти 3 використання теле-, радіо- та інтернет зв'язку. Велика частина відповідальності за повноту отриманих знань була покладена безпосередньо на студентів, або, у випадку учнів шкіл, на їх батьків. Окрім того, навчальні заклади були змушені адаптувати систему оцінювання знань та суттєво зменшили обсяги інформації для засвоєння. [1].

Та, на жаль, велика кількість навчальних закладів виявилась неготовою до викликів пандемічної реальності. Деякі заклади освіти попросту не мали відповідного технічного обладнання для впровадження принципів дистанційної освіти. Це в більшій мірі стосується тих закладів освіти, які знаходились в сільській місцевості, або ж в країнах з нестабільної економічною ситуацією. До того ж, варто зауважити про те, що не всі одержувачі освітніх послуг мали змогу забезпечити вдома відповідні технічні умови для використання засобів дистанційної освіти.

Сьогодні, в результаті пандемії, в країнах з низьким і середнім рівнем доходів пандемія призвела до скорочення запланованого збільшення витрат на освіту в 2020 році. Згідно 3 прогнозами, зробленими до пандемії, державні витрати на освіту в усіх регіонах і групах доходів в реальному вираженні повинні були зростати. Однак базові прогнози, були хибні через впровадження карантину, і витрати суттєво зросли для країн з низьким і середнім рівнем доходів. В кінцевому випадку, витрати на освіту на душу населення скоротилися майже у всіх групах країн з доходом і у всіх регіонах. Наприклад, витрати на освіту на душу населення в країнах Африки на південь від Сахари знизилися на 4,2 відсотка.

Проблеми впровадження та реалізації методів та технологій дистанційної освіти були і в тих закладах, які були повністю оснащені для дистанційної освіти в технічному плані. Далеко не всі педагоги змогли адаптувати свої 
застарілі педагогічні навички до сучасних викликів та почати викладати за допомогою інноваційних освітніх платформ дистанційної освіти. Це стосувалось в більшій мірі педагогів пострадянського простору. Найбільш швидко змогли пристосуватись до нових умов викладання ті педагоги, які працювали в міжнародних освітніх закладах, так як вони вже довгий час використовували медійні та дистанційні засоби у власному робочому процесі.

Опинившись в стані карантинних обмежень та усвідомивши важливість оперативного реагування, уряди деяких країн, міжнародні організації та впливові науковці були змушені шукати короткострокові рішення на найбільш нагальні проблеми в сфері карантинної освіти.

В свою чергу велика кількість країн на національному рівні почали впроваджувати заходи допомоги та підтримки власної системи освіти. На сьогоднішній день всі ці заходи можна розділити на наступні категорії [2, с. 99]:

1. Інформаційна підтримка системи освіти на регіональному та загальнодержавному рівні.

2. Надання рекомендацій для різних сфер системи освіти щодо дотримання санітарно-епідеміологічних заходів превенціїі коронавірусної хвороби.

3. Реалізація адміністративних заходів щодо підтримання та збереження функціонування закладів освіти різних розмірів та рівнів акредитації.

4. Гнучкість та допомога в процесі формування та здачі звітності та проходженні акредитаційних програм, а також послаблення вимог щодо якості організації онлайн- та дистанційного навчання.

5. Формування сприятливого середовища, яке дасть можливість реалізувати всі аспекти дистанційного навчання та онлайн-навчання.

6. Всебічна фінансова підтримка сфери освіти.

7. П Підтримка міжнародної освіти та академічної мобільності за умов карантинних обмежень, пошук шляхів розв'язання логістичних проблем.

8. Підтримка університетських досліджень та лабораторій.

9. Підтримка спеціальних ініціатив щодо підтримки та збереження психологічного здоров'я студентів та викладачів.

До прикладу, організація економічного співробітництва та розвитку та Гарвардська вища школа освіти в 2020 році опублікувала «Рекомендації щодо відповідностей освіти в часи пандемії 2020 році» [3]. В даних рекомендаціях акцентується увага на важливості формування адаптивної стратегії реалізації освітнього процесу в часи пандемічних обмежень, при цьому наголошується важливість формування чітких планів 3 врахуванням особливостей дистанційного навчання. В результаті використання даних рекомендацій, стало можливим мінімізувати порушення в навчальному процесі, а також продовжити формувати в студентів та учнів ті навички та компетентності, які $є$ 
важливими в сучасному світі, в умовах дистанційного навчання.

3 огляду на це, в освітній сфері сформувались декілька напрямків дистанційного навчання (табл.1).

Таблиия 1

\section{Основні напрямки дистанційного навчання}

\begin{tabular}{|c|c|}
\hline № & Суть напрямку \\
\hline 1 & $\begin{array}{l}\text { Організація освітнього процесу з використанням доступних } \\
\text { онлайн-платформ }\end{array}$ \\
\hline 2 & Передача освітньої інформації за допомогою теле-та радіоканалів \\
\hline 3 & $\begin{array}{l}\text { Проведення освітніх занять } 3 \text { допомогою соціальних мереж, } \\
\text { електронної розсилки та менеджерів }\end{array}$ \\
\hline 4 & $\begin{array}{l}\text { Збільшення тиражу «матеріальних» копій підручників та пересилання } \\
\text { останніх у віддалені регіони, з безпечною доставкою на дім }\end{array}$ \\
\hline
\end{tabular}

Сформовано на основі досліджуваних джерел: [4]

Усвідомивши важку пандемічну ситуацію в світі та той факт, що вона не має тенденції до змін, спеціалісти ЮНЕСКО усвідомили важливість та актуальність розвитку дистанційної освіти. 3 огляду на це, вони створили «основну класифікацію інструментів» для організації дистанційного навчання в освітніх закладів по всьому світу [5]:

- ресурси, які направлені на забезпечення психосоціальної підтримки основних учасників освітнього процесу в умовах карантинних обмежень;

- системи менеджменту дистанційною та цифровою освітою, такі як Moodle, Google classroom, Blackboard та Canvas;

- мобільні додатки для навчання, які можуть використовуватись як для передачі знань між викладачем та студентом, так і для проведення поточного контролю засвоєних знань;

- програми з розширеною онлайн-функціональністю;

- державні та комерційні сервіси самостійного навчання;

- електронні рідери;

- масові відкриті онлайн-курси;

- цифрові платформи, які дають можливість проводити освітні заняття в онлайн-режимі, такі як Zoom, Skype та WebEx);

- програмне забезпечення, яке дає можливість створити цифрові форми навчального контенту, а також електронні бази навчальної інформації

Багато учбових закладів вбачають в такому різкому та неочікуваному переході з застарілих форм навчання на нові лише недоліки та складнощі. Але деякі науковці зауважують той факт, що така ситуація може бути тим самим 
довгоочікуваним бустером для світової освітньої системи, яка вже десятиліттями потребує нововведень та інновацій.

Освітні установи можуть випробувати ефективність пропонованих цифрових рішень, визначити свої потреби в технологічній модернізації, в разі необхідності продумати питання організації перепідготовки та додаткового навчання викладачів.

Крім того, вимушена самоізоляція сприяє і деяких позитивних суспільних змін: зростає інтерес до самонавчання через онлайн-сервіси, великі видавництва відзначають підвищення попиту на навчальні матеріали в цифровому форматі.

3 огляду на вищесказане, пандемія COVID-19 стала визначальним явищем останніх десятирічь та вплинула на всі сфери життя людей.

Підсумовуючи, зазначимо, що COVID-19 - це пандемічне захворювання, викликане вірусом, що вражає систему освіти як в країнах, що розвиваються, так і в розвинених країнах. Освіта - це основа розвитку кожної країни. У світі більшість шкіл, коледжів i університетів закриті, щоб контролювати поширення COVID-19. Закриття школи створює труднощі для учнів, сімей i вчителів. Отже, дистанційне навчання - це рішення для продовження системи освіти. Однак дистанційне навчання $є$ складним завданням в країнах, що розвиваються.

Висновки. Пандемія COVID-19 змусила всі освітні школи по всьому світу перейти на викладання і навчання в Інтернеті. Таким чином, урядам слід масштабувати мережеву інфраструктуру і підключення до Інтернету в міських i сільських районах. Країни повинні розробити стратегію масштабування освітніх технологій, створити освітні ресурси 3 нульовим рейтингом в Інтернеті, підготувати цифрові ресурси для викладання i навчання, використовувати безкоштовні ресурси для онлайн-навчання, використовувати мобільний навчання, використовувати радіо і телебачення, а також розвивати інфраструктуру інформаційно-комунікаційних технологій. Країни, що розвиваються повинні масштабувати інфраструктуру онлайн-навчання.

\section{Jimepamypa:}

1. OECD A Framework to Guide an Education Response to the Covid-19 Pandemic of 2020. Paris: Organisation for Economic Cooperation and Development

2. COVID-19 and higher education: Today and tomorrow. Impact analysis, policy responses and recommendations // UNESCO IESALC. 13.05.2020. URL: https://www.iesalc.unesco.org/en/wp-content/uploads/2020/05/COVID-19-EN-130520.pdf

3. OECD, Education Responses To Covid-19: Embracing Digital Learning And Online Collaboration, https://oecd.dam-broadcast.com/pm_7379_120_120544-8ksud7oaj2.pdf

4. COVID-19 Educational Disruption and Response. UNESCO. URL: https://en.unesco.org/covid19/educationresponse

5. Distance learning solutions. UNESCO. URL: https://en.unesco.org/covid19/educationresponse/ solutions 


\section{References:}

1. OECD (2020) A Framework to Guide an Education Response to the Covid-19 Pandemic of 2020. Paris: Organisation for Economic Cooperation and Development [in English]

2. COVID-19 and higher education [2020]: Today and tomorrow. Impact analysis, policy responses and recommendations // UNESCO IESALC. 13.05.2020. URL: https://www.iesalc.unesco.org/en/wp-content/uploads/2020/05/COVID-19-EN-130520.pdf [in English]

3. OECD (2020), Education Responses To Covid-19: Embracing Digital Learning And Online Collaboration, https://oecd.dam-broadcast.com/pm_7379_120_120544-8ksud7oaj2.pdf [in English]

4. COVID-19 (2020) Educational Disruption and Response. UNESCO. URL: https://en.unesco.org/covid19/educationresponse [in English]

5. Distance learning solutions (2020). UNESCO. URL: https://en.unesco.org/covid19/ educationresponse/solutions [in English] 